\title{
„Nie ptak, nie samolot, a dziewczyna”. Wizje kobiecej dorosłości w Lekkiej księżniczce George'a MacDonalda i jej adaptacji na musical Tori Amos i Samuela Adamsona
}

\section{Abstrakt:}

W artykule poddano analizie baśń George’a MacDonalda Lekka księżniczka (1864) i jej musicalową adaptację wystawioną w 2013 roku na deskach Royal National Theatre w Londynie. Autorami libretta są dramatopisarz Samuel Adamson i piosenkarka Tori Amos, która napisała również muzykę na potrzeby spektaklu. Jednym z głównych tematów baśni jest dojrzewanie księżniczki pozbawionej ciężaru i zdolności odczuwania smutku, a także jej proces stawania się w pełni ukształtowaną dorosłą kobietą. Autorka artykułu wykazuje podobieństwa i różnice między oryginałem powstałym pod koniec XIX wieku a jego adaptacją z początku XXI wieku i ich związki ze schematami baśni ludowej. Analiza pozwala nie tylko zbadać wizję dorosłości, którą przedstawia w swoim dziele MacDonald, lecz także wykazać, w jaki sposób mogły się zmienić definicje dorosłości i kobiecości na przestrzeni stu lat znaczących dynamiczny rozwój praw kobiet. Jak dowodzi autorka, w przeciwieństwie do MacDonalda, który świadomie przetwarza wiele baśniowych wątków, Adamson i Amos wprowadzają do tekstu współczesne elementy, nie integrując ich z adaptowaną baśnią literacką czy też jej ludowymi inspiracjami. Jednocześnie, chcąc stworzyć nowoczesną, feministyczną wersję XIX-wiecznej baśni, Adamson i Amos nierzadko osiągają skutek odwrotny do zamierzonego.

Słowa kluczowe:

adaptacja, baśń, dojrzewanie, feminizm, gender, George MacDonald, Lekka księżniczka, musical, Samuel Adamson, Tori Amos

* Natalia Kuc - mgr, badaczka niezależna. Jej zainteresowania badawcze obejmują historię oraz teorię literatury dziecięcej, młodzieżowej i fantastycznej, historię i teorię przekładu oraz historię i teorię dzieł kultury popularnej, ze szczególnym uwzględnieniem społeczności fanowskich i ich twórczości w różnych mediach. Kontakt: kuc.natalia@gmail.com. 
"Not a Bird, not a Plane, a Girl": Visions of Female Adulthood in George MacDonald's The Light Princess and Its Musical Adaptation by Tori Amos and Samuel Adamson

\section{Abstract:}

The aim of the paper is to analyse The Light Princess (1864), a fairy tale by George MacDonald, and its musical adaptation from 2013 staged in the Royal National Theatre in London. The authors of the lyrics are Samuel Adamson, a playwright, and Tori Amos, a singer, who is also responsible for the music in the show. The fairy tale tells the story of a young princess cursed to be devoid of weight and the ability to feel sadness, as well as of her process of maturing into an adult woman. The author of the paper presents similarities and differences between the original tale dating to the late $19^{\text {th }}$ century and its $21^{\text {st }}$ century adaptation, along with their ties to folktale tropes. The analysis aims not only to set forth the vision of adulthood as described by MacDonald, but also to propound how the definitions of adulthood and womanhood could have changed over the course of a century of dynamic emancipation of women. According to the author, while MacDonald consciously subverts multiple fairy tale tropes, Adamson and Amos introduce modern elements to the text without integrating them into the fairy tale adaptation and with little regard for its folk inspirations. Driven by the desire to rewrite a modern, feminist version of the $19^{\text {th }}$ century fairy tale, Adamson and Amos often achieve opposite results.

\section{Key words:}

adaptation, fairy tale, adolescence, feminism, gender, George MacDonald, The Light Princess, musical, Samuel Adamson, Tori Amos

Cekka księżniczka to baśń autorstwa George’a MacDonalda (1864/2017a), ra literatury fantastycznej. Utwór opowiada o królewnie obarczonej „lekkością ducha i ciała" w wyniku klątwy czarownicy (s. 10). W 2013 roku doczekał się nowoczesnej adaptacji na musical, do którego piosenki napisała wraz z Samuelem Adamsonem Tori Amos, gwiazda muzyki niezależnej znana $\mathrm{z}$ feministycznego aktywizmu. Oba teksty to opowieści o często bolesnym dojrzewaniu do bycia dorosłym człowiekiem. Oba też starają się odpowiedzieć na pytania, co właściwie oznacza bycie w pełni ukształtowanym człowiekiem i jakie losy mogą czekać młodszych odbiorców baśni i musicalu. Lekka księżniczka w obu wersjach podejmuje zatem przede wszystkim temat przyszłości, a także wyzwań, obaw i nadziei z nią związanych.

Choć niewątpliwie dzieło późniejsze jest mocno osadzone w swoim literackim oryginale, wizje dorastania i dorosłości przedstawione w baśni i w jej 
adaptacji znacząco różnią się między sobą. To spostrzeżenie może wydawać się oczywiste - teksty dzieli niemal sto pięćdziesiąt lat przemian społecznych i kulturowych. Przemian o tyle widocznych, że oba dzieła w sposób zdecydowany i naznaczony charakterem czasów, w których powstawały, podejmują tematykę związaną z płcią głównej bohaterki. Tytułowa księżniczka musi z dziewczynki przemienić się w kobietę, której w swoim czasie przypadają konkretne role: następczyni tronu, matki czy partnerki - żony lub kochanki. Tym samym trudno nie rozważać obu opowieści w szerszym, a fascynującym kontekście kobiety jako bohaterki lub odbiorczyni baśni i mitu.

Zwłaszcza wersja musicalowa Lekkiej księżniczki wpisuje się w nowoczesny nurt feministycznych reinterpretacji znanych baśni i mitów. O jego popularności szczególnie wśród pisarek amerykańskich i brytyjskich pisze Grażyna Lasoń-Kochańska (2004): „Opowiadając znane wątki na nowo, bądź przedstawiając ich liczne wersje, autorki wpisują się w feministyczny dyskurs; reinterpretują rzekome uniwersalia, tkwiące u korzeni kultury" (s. 173). Lasoń-Kochańska przywołuje liczne przykłady podobnych działań, od opartych na baśniach opowiadań Angeli Carter, wydanych w Polsce w zbiorczym tomie Czarna Wenus (2000), przez Mgły Avalonu Marion Zimmer Bradley (1982/2018), aż po twórczość Jeanette Winterson (Płeć wiśni; 1989/1997) czy Ursuli K. Le Guin (opowiadanie Odkrycia z tomu Otwarte przestworza; 1996/2001). Warto przy tej okazji dodać, że feministyczna dekonstrukcja baśni przestaje być jedynie domeną kobiet pisarek. Wątki, które analizują i przetwarzają rolę kobiet $\mathrm{w}$ opowieściach zaczerpniętych $\mathrm{z}$ folkloru, odnaleźć można m.in. w książkach poświęconych wiedźmom z cyklu powieściowego Terry’ego Pratchetta o Świecie Dysku czy w wybranych utworach Neila Gaimana, jak choćby opowiadania Szkło, śnieg i jabłka z tomu Dym i lustra. Opowiadania i złudzenia (1998/2002) czy Śpiąca i wrzeciono z tomu Drażliwe tematy. Krótkie formy i stany zapalne (2015).

Tego typu przekształcenia należą do szerszego trendu „aktualizacji” treści tradycyjnych baśni i ich znaczenia tak, aby przystawały do współczesnego obrazu świata oraz wyzwań, wartości i postaw, które w nim dominują ${ }^{1}$ Zarówno oryginalny tekst MacDonalda, jak i tekst adaptacji Amos i Adamsona można zaliczyć raczej do gatunku nowoczesnej baśni literackiej - choć Lekka księżniczka wykorzystuje wiele motywów znanych z baśni ludowej, często zrywa ona $\mathrm{z}$ jej schematami fabularnymi, czyniąc ją tym samym osobnym dziełem

1 O tendencji tej pisze m.in. Kaja Klimek (2011) w artykule dla Dwutygodnika zatytułowanym Baśnie księżniczki popkultury. 
literackim ${ }^{2}$. Liczne aluzje $\mathrm{z}$ dziedzin literatury, filozofii czy socjologii $\mathrm{w}$ obu wersjach służą nie tylko uwspółcześnieniu struktur opowieści znanych z baśni, ale przede wszystkim wyrażeniu poglądów autorów.

Biorąc pod uwagę burzliwy i intensywny rozwój myśli feministycznej na przestrzeni XX wieku oraz osobiste zaangażowanie w tę tematykę Amos, logiczne byłoby założenie, że jej współczesna wersja opowieści o lekkiej księżniczce będzie różniła się od oryginału prezentowaną wizją kobiecości. Zarówno pojmowanie społecznej roli kobiet, jak i stawiane przed nimi na każdym etapie życia zadania uległy wszak znacznym przekształceniom w ciągu ostatnich stu pięćdziesięciu lat, zwłaszcza, choć nie tylko, w kulturze zachodniej. Czy zatem nowoczesna adaptacja baśni o dojrzewającej księżniczce wypada bardziej aktualnie, jeśli chodzi o obraz kobiecej dorosłości?

Autor pierwotnego tekstu baśni jest obecnie twórcą nieco zapomnianym, szczególnie w Polsce, gdzie wydano dotychczas zaledwie niewielką część jego twórczości. Tymczasem MacDonald stworzył podwaliny nowoczesnej literatury fantastycznej (Johnson, 2014). Za życia był przyjacielem, krytykiem i mentorem takich pisarzy jak Lewis Carroll, John Ruskin, Walt Whitman czy Mark Twain, a wiele lat po jego śmierci do inspiracji dziełami MacDonalda przyznawali się m.in. J. R. R. Tolkien czy C. S. Lewis. G. K. Chesterton (1924, s. 9) we wstępie do biografii MacDonalda wspomina książkę The Princess and the Goblin (1872/2011) jako tę, która „odmieniła całą jego egzystencję, pomogła [mu] zobaczyć świat w inny sposób [...]”3, a jej pierwszą lekturę porównuje do zmiany wyznania religijnego. Uznanie przyniosły MacDonaldowi powieści zarówno dla dorosłych, jak i dla dzieci. Polskiemu czytelnikowi może być on jednak znany przede wszystkim jako autor dla młodych odbiorców. Niestety, lwia część dorobku pisarza nie została jeszcze przetłumaczona na język polski. Jako pierwsza w naszym kraju, jeszcze w 1958 roku, ukazała się książka Na skrzydłach Pótnocnej Wichury w tłumaczeniu Ireny Tuwim (1871/1958). Następnie przez kilkadziesiąt lat nikt nie interesował się wprowadzaniem twórczości MacDonalda na rynek polski. Dopiero przełom wieków przyniósł ze sobą zaledwie kilka wydań jego powieści dla dzieci, przede wszystkim pozycji The Princess and the Goblin (1872/2011), która ukazała się w aż trzech przekładach: w 1990, 2005 oraz 2012 roku. Wreszcie w roku 2017 nakładem wydawnictwa „W drodze” ukazała się zbiorcza edycja trzech opowiadań MacDonalda: Lek-

2 Różnice między baśnią ludową a literacką oraz inspiracje, jakie z tej pierwszej czerpie ta druga, omawia m.in. Violetta Wróblewska (2003) w książce Przemiany gatunkowe polskiej baśni literackiej XIX i XX wieku.

3 Jeśli nie podano inaczej, wszystkie tłumaczenia autorki artykułu - Natalii Kuc. 
kiej księżniczki (1964/2017a), Złotego klucza (1967/2017c) oraz Serca olbrzyma (1964/2017b) w tłumaczeniu Emilii Kiereś i z ilustracjami Izabelli Czarneckiej. Lekka księżniczka to wariacja na temat schematu opowieści o Śpiącej Królewnie - stąd zwłaszcza jej początkowe fragmenty mogą wydawać się znajome. Tytułowa księżniczka zostaje przeklęta przez złą czarownicę, a jednocześnie swoją ciotkę, księżnę Danauke, w odwecie za brak zaproszenia na chrzciny księżniczki. Czarownica rzuca na dziecko klątwę, w wyniku której księżniczka ma zachować wieczną „lekkość ducha i ciała”. Oznacza to, że dziewczynka nie jest w stanie odczuwać smutku, ale też zupełnie nie podlega sile grawitacji - MacDonald (1864/2017a) usłużnie wyjaśnia, że „księżna [Danauke] była filozofem i wszelkie prawa przyciągania znała od podszewki, równie dobrze jak wszystkie szczegóły dotyczące jej własnego sznurowadła” (s. 12). Klątwa jest podwójnie sroga. Księżniczka może poruszać się jedynie przywiązana do szarf lub przytrzymując się przedmiotów przymocowanych do ziemi - w przeciwnym razie grozi jej porwanie przez wiatr. Jednocześnie dziewczynka nie potrafi odczuwać innych emocji niż nieograniczona wesołość. Zarówno jej własna przypadłość, jak i wszystko i wszyscy wokół powodują u niej jedynie wybuchy śmiechu. Księżniczka odzyskuje ciężar ciała jedynie w wodzie, dlatego też spędza długie godziny w przyzamkowym jeziorze. Doradcy króla sugerują zatem, że pomóc mogłaby „woda z głębszego źródła” (s. 33), tj. że doprowadzenie jego córki do płaczu mogłoby przełamać klątwę. Jest to jednak niemożliwe - humoru księżniczce nie psuje ani smutna opowieść żebraka, ani jej własny lęk przed podmuchami wiatru, ani nawet gniew ojca. Innym sugerowanym lekarstwem jest „wpadnięcie po uszy w miłość” (s. 29) - to, oczywiście, gra słów, która lepiej wypada w języku oryginału [to fall in love]. Dziewczyna kocha jednak tylko jezioro. To w nim znajduje ją książę z pobliskiego królestwa. Spędzają wiele nocy na wspólnym pływaniu. Kiedy zła księżna Danauke próbuje wysuszyć jezioro, młodzieniec zgłasza się na ochotnika, aby zatkać dziurę w dnie własnym ciałem, pod warunkiem że księżniczka będzie mu towarzyszyć do ostatnich chwil. Kiedy książę powoli tonie, ta zachowuje dobry humor, ucieszona perspektywą odzyskania ukochanego jeziora. Dopiero kiedy jej towarzysz niknie całkowicie pod wodą, księżniczkę dopada przerażenie. Z narażeniem własnego życia wyciąga księcia $\mathrm{z}$ wody, a kiedy ten po wielu godzinach odzyskuje przytomność, dziewczyna wybucha płaczem. Jednocześnie orientuje się, że klątwa została z niej zdjęta.

Lekka księżniczka łączy w sobie wątki komiczne z dramatycznymi. Liczne żarty słowne i humorystyczne obserwacje dotyczące życia społecznego, więzi międzyludzkich czy współczesnych autorowi trendów w nauce łączą się z przejmującymi prawdami o życiu i świecie. Jednym z najciekawszych wątków jest 
jednak temat dorastania, a przede wszystkim tego, co oznacza doświadczanie życia w pełni, jako dorosły.

Lekka księżniczka wpisuje się w długą tradycję traktowania baśni jako opowieści przygotowujących dziecko do wejścia w dorosłość, o czym pisało wielu badaczy tego gatunku, od Brunona Bettelheima (1976/2010) w monografii Cudowne i pożyteczne. O znaczeniach i wartościach baśni po Jacka Zipesa (1983/2012), który już we wczesnych swoich książkach zgłębiał sposób, w jaki wykorzystywano baśnie do kształtowania postaw. W wizji świata prezentowanej przez Lekką księżniczkę dorosłość to przede wszystkim zdolność odczuwania wszystkich emocji właściwych człowiekowi, doświadczania tego, co złe, na równi z tym, co dobre. Lekkość głównej bohaterki jest tu metaforą odrzucenia odpowiedzialności i bólu związanych z dojrzewaniem. Księżniczka nie chce czy też nie może dorosnąć, dlatego skazana jest na wieczne dryfowanie i izolację, zarówno od ziemi w jej najbardziej dosłownym sensie, jak i od innych ludzi, w tym najbliższych. Nieustający dobry humor dziewczyny od samego początku przedstawiony zostaje jako przekleństwo:

[...] królewna śmiała się jak sam duch dobrej zabawy, tyle tylko że w jej śmiechu czegoś brakowało. Co to było takiego - nie potrafię opisać. Myślę, że chodziło o pewien szczególny odcień, który pojawia się tylko tam, gdzie istnieje możliwość odczuwania smutku - być może morbidezza. Królewna nigdy się nie uśmiechała (MacDonald, 1864/2017a, s. 22).

Co ciekawe, MacDonald decyduje się tutaj na użycie włoskiego rzeczownika, który oznacza miękkość, łagodność, a który jednocześnie musi kojarzyć się w tekście oryginału, zwłaszcza w obrębie danego akapitu, z angielskim słowem morbid, oznaczającym coś chorobliwego, makabrycznego. Słownik Merriam-Webster wskazuje zresztą na wspólny źródłosłów łaciński obu tych słów - morbidus oznaczać może coś niezdrowego, chorowitego czy źle funkcjonującego (b.a., b.d.a, b.d.b). Taki wybór ze strony MacDonalda, mistrza gier słownych, zapewne nie jest przypadkowy. Służy podkreśleniu nienaturalnego stanu księżniczki. Jak słusznie zauważa Amy Billone (2004), choć protagonistka otoczona jest miłością, jej szczególna przypadłość budzi też strach m.in. rodziców i piastunki (s. 137). Śmiech bohaterki z wiekiem staje się coraz bardziej niepokojący, do tego stopnia, że kiedy książę słyszy go pierwszy raz nad jeziorem, bierze go za krzyk przerażenia osoby tonącej i rzuca się dziewczynie na pomoc.

Dziecięca beztroska zamienia się w opowieści MacDonalda w klątwę, która więzi księżniczkę i nie pozwala jej dorosnąć, podjąć obowiązków córki i następczyni tronu, ani nawet kochać, zamieniając ją tym samym pośrednio 
w pozbawionego empatii potwora. Choć księżniczka spędza z księciem całe dnie, nie chce rozmawiać o miłości; zbywa i wyśmiewa wszystkie próby podejmowania tematu przez zakochanego młodzieńca, nawet kiedy ten przez wiele godzin topi się na jej oczach. W ostatnich słowach prosi on królewnę, by go pocałowała, a ta składa na jego ustach pocałunek opisany przez MacDonalda (1864/2017a) jako „długi, słodki i zimny” (s. 64). Koniec baśni pozostawia jako otwartą kwestię, czy to łzy, czy też uczucie do księcia przywracają księżniczce grawitację. Nie ma to jednak znaczenia - miłość i cierpienie są ze sobą bowiem nierozerwalnie związane. MacDonald wprowadza w swojej baśni niejako triadę śmierć - miłość - życie, stawiając między wszystkimi trzema znak równości. Miłość do księżniczki każe księciu oddać się śmierci. Ta sama miłość ratuje mu jednak życie. Kulminacyjna scena baśni, w której dziewczyna obserwuje w milczeniu, jak woda zalewa powoli twarz chłopaka, to zetknięcie bohaterki z miłością i śmiercią jednocześnie. MacDonald każe swojej bohaterce dosłownie i metaforycznie spojrzeć śmierci w twarz - jest to jednak jednocześnie twarz księcia, która uosabia obietnicę uczucia i radości.

Tylko cierpienie pozwala odczuwać prawdziwe szczęście, tylko łzy mogą sprawić, że księżniczka będzie zdolna do prawdziwego uśmiechu. Dojrzewanie do dorosłości jest równoznaczne z dojrzewaniem do bólu. U bohaterki proces ten zostaje zahamowany na etapie dziecięcym, a następnie gwałtownie przyspieszony. Podkreślają to ostatnie sceny opowieści, w których dziewczyna uczy się chodzić. Choć często upada, książę jest przy niej, by ją wspierać. Ciężar pozwala jej też wpadać $\mathrm{z}$ księciem do jeziora $\mathrm{z}$ wielkim pluskiem, co staje się jedną z jej ulubionych rozrywek. Baśń MacDonalda uczy, że jedynie zdolność odczuwania smutku pozwala odczuwać prawdziwą radość, tym większą, jeśli jest ona dzielona $\mathrm{z}$ drugą osobą.

W 2013 roku Lekka księżniczka doczekała się adaptacji na musical na deskach National Theatre w Londynie. Autorami libretta opartego na książce MacDonalda są dramatopisarz Samuel Adamson oraz piosenkarka Tori Amos (2013), która skomponowała również muzykę na potrzeby spektaklu. Warto tu nadmienić, że produkcja kojarzona jest szczególnie z nazwiskiem Amos. Wpływ na to mają zarówno jej rozpoznawalność jako światowej gwiazdy muzyki alternatywnej, jak i znacząca, być może nawet decydująca, rola artystki w procesie powstawania adaptacji, której jest też pomysłodawczynią (Belcher, 2013). Co więcej, treść musicalu, a szczególnie poczynione zmiany adaptacyjne, eksplorują obszary tematyczne charakterystyczne dla solowej twórczości Amos. Emancypacja kobiet, wykluczenie ze społeczeństwa, dojrzewanie czy macierzyństwo to tylko niektóre z zagadnień, z którymi mierzą się bohaterowie spektaklu, a które piosenkarka zgłębia w swoich utworach. Tematy te 
towarzyszą Amos przez całą karierę, od debiutanckiego solowego albumu Little Earthquakes (1992), na którym można usłyszeć m.in. Me and a Gun - utwór opowiadający o napaści seksualnej, której ofiarą padła Amos po koncercie aż po bliższe współczesności płyty Beekeeper (2005) czy American Doll Posse (2007), poświęcone szczególnie światom religii i polityki oraz roli, jaką odgrywają w nich kobiety. Liczne powiązania między tematyką piosenek Amos a losami bohaterów musicalu mogą wskazywać na to, że to właśnie artystka była odpowiedzialna za wyznaczenie głównych ram tematycznych i narracyjnych nowej wersji opowieści o lekkiej księżniczce.

Treść musicalu różni się w znacznym stopniu od baśni MacDonalda. Nadal jest to historia o księżniczce przeklętej brakiem fizycznego ciężaru i zdolności odczuwania smutku, która spotyka księcia i zakochuje się w nim. Kiedy jego życiu zagraża niebezpieczeństwo, dziewczyna płacze, odzyskując tym samym „ciężar ducha i ciała” (MacDonald, 1864/2017a, s. 10). Wiele wątków zostaje jednak rozwiniętych, skróconych lub całkowicie zmienionych. Część zmian typowych jest dla procesu adaptacji krótkiej baśni dla dzieci na ponad dwugodzinny musical dla młodszych i starszych widzów. W ten sposób można wyjaśnić np. nadanie głównym postaciom imion (Althea oraz Digby) czy pojawienie się postaci drugoplanowych, takich jak Piper, przyjaciółka i powiernica księżniczki Althei. Wydaje się jednak, że wiele zmian jest bezpośrednim następstwem celów, które obrali sobie Amos i Adamson, adaptując baśń MacDonalda na potrzeby teatru muzycznego.

Odpowiedzi na pytanie, jakie ambicje i motywacje kierowały twórcami libretta, można szukać w materiałach promocyjnych spektaklu oraz w wywiadach z samymi pisarzami publikowanych w ramach kampanii reklamowej. $\mathrm{W}$ programie rozdawanym $\mathrm{w}$ teatrze National Theatre znalazły się dwa eseje. Autorką pierwszego z tekstów jest Marina Warner (2013), brytyjska pisarka znana m.in. ze swoich często kontrowersyjnych ${ }^{4}$ prac badawczych poświęconych funkcjonowaniu pierwiastka kobiecego w mitach, baśniach i tradycji ludowej oraz religijnej. Esej Writing to the Future jest swego rodzaju wprowadzeniem do twórczości MacDonalda, ze szczególnym uwzględnieniem jej

4 Nazwisko badaczki kojarzone jest przede wszystkim z jej serią publikacji dotyczących postaci Matki Boskiej w tradycji katolickiej, z których pierwszą była praca Alone of All Her Sex: The Myth and the Cult of the Virgin Mary (Warner, 1976/2016). Tytuł ten zapewnił autorce na pewien czas częstą obecność w mediach i w świadomości publicznej, co też udokumentował zespół Dire Straits w piosence Lady Writer (Knopfler, 1979). Wybór postaci tak silnie kojarzonej z feministycznym nurtem badawczym na autorkę eseju umieszczonego w materiałach promocyjnych może wskazywać na dużą wagę, jaką autorzy libretta przywiązywali do zagadnień tego nurtu. Zob. też Gleick (1999). 
humorystycznego, uniwersalnego i metaforycznego charakteru, który badaczka łączy z epoką wiktoriańską. W pierwszej kolejności Warner opisuje jednak historię przemian w odbiorze baśni na przestrzeni XX wieku, od złagodzonych z myślą o najmłodszym widzu wersji znanych z filmów Disneya, przez ich krytykę w latach 60. i 70., aż po czasy transformacji, które trwają do dziś, a w których powracają baśnie wyzwolone, często zgłębiające najmroczniejsze obszary ludzkiej psychiki. Badaczka podkreśla udział kobiet i znaczenie kobiecej perspektywy w opowiadaniu baśni na nowo, przywołując postaci Angeli Carter, jak również samej Amos, która w swojej twórczości wielokrotnie odwołuje się do archetypicznych baśniowych postaci i motywów. Warner zauważa, że musical Amos i Adamsona wykorzystuje historię lekkiej księżniczki do tego, aby skonfrontować się z licznymi problemami współczesności, wśród których pisarka wymienia przede wszystkim przemoc seksualną i przynależne młodym kobietom „rozpaczliwe, eskapistyczne poszukiwanie odrętwienia i zobojętnienia w alkoholu, narkotykach, zaburzeniach odżywiania, samookaleczaniu, a nawet śmierci" (s. [27]).

Podobne tezy prezentuje drugi esej, który znalazł się w programie, a którego autorką jest Tanya Byron (2013), specjalistka w dziedzinie psychologii dzieci i młodzieży. Tekst o znamiennym tytule The Trouble with Girls poświęcony jest głównie problemom okresu dojrzewania, z którymi mierzą się dziewczęta na progu XXI wieku, takim jak poczucie odrzucenia czy zaburzenia poczucia własnej wartości. Choć Byron zauważa, że niemal od zarania dziejów młodzież narażona była na krytykę tych dorosłych, którzy widzieli w młodszych pokoleniach zagrożenie dla ustalonego porządku, podkreśla, że nowa era mediów i kultu celebrytów przyniosła ze sobą nowe wyzwania i zagrożenia dla młodych ludzi. Zdaniem Byron, taki stan rzeczy jest szczególnie trudny dla dorastających dziewcząt, które muszą zmagać się z kulturową i systemową dyskryminacją, a także nieosiągalnymi, a licznymi oczekiwaniami ze strony społeczeństwa. Autorka przywołuje w tekście opracowane przez Juliana B. Rottera (1966) pojęcie poczucia umiejscowienia kontroli [locus of control, LOC], aby wyjaśnić wzrastający wśród młodych kobiet odsetek autoagresywnych zachowań, od samookaleczania się po zaburzenia odżywiania. W skazanej na porażkę pogoni za dorównaniem ideałom znanym $\mathrm{z}$ mediów wiele dziewcząt przestaje kierować się własnymi przekonaniami, a zamiast tego oddaje kontrolę nad swoim życiem czynnikom zewnętrznym.

Dobór tematyki obu publikacji oraz postaci ich autorek może wskazywać na to, że w procesie adaptacji baśni MacDonalda na scenę autorzy libretta kierowali się chęcią unowocześnienia opowieści tak, aby ukazywała problemy, z którymi borykają się współcześnie młodzi ludzie, zwłaszcza kobiety. 
Potwierdzenie tych przypuszczeń można znaleźć także w słowach twórców, którzy w wywiadach wielokrotnie wypowiadają się o potrzebie emancypacji głównej bohaterki i nadania oryginalnej historii mroczniejszego charakteru. W materiałach edukacyjnych publikowanych na stronie internetowej National Theatre Adamson tak opisuje pracę nad adaptacją:

[...] odkryliśmy, że niektórych aspektów [Lekkiej księżniczki] nie da się przełożyć na opowieść z silną, wyraźnie współczesną główną bohaterką. To był największy problem. W oryginale [księżniczka] jest dość bierna - trudno to zaadaptować, bo bierne postaci nie sprawdzają się na scenie, bohaterowie muszą czegoś pragnąć (Foster, 2014, s. 17).

Sama Amos w wywiadzie dla serwisu Nylon (Kaplan, 2015) jako najważniejsze w adaptacji wskazuje tematy radzenia sobie ze stratą i często toksycznego wpływu rodziców na kształtowanie osobowości dzieci. To nastolatkowie wchodzący w dorosłe życie są według niej główną grupą odbiorczą musicalu - stąd też chęć uwspółcześnienia baśni i wprowadzenia do niej nowych wątków, również takich, które mogłyby zostać uznane za kontrowersyjne, takich jak seksualność młodych bohaterów.

W książce poświęconej współczesnym przekształceniom baśni Weronika Kostecka (2014) podkreśla, że feministyczne transformacje gatunku nie tylko mają na celu opisanie zastanej rzeczywistości, lecz także niosą ze sobą nadzieję na jej odmianę. Jak pisze badaczka:

[...] aby przeciwstawić się negatywnemu obrazowi kobiecości, feministki zaczęły samodzielnie pisać baśnie - reinterpretować te znane z tradycji i tworzyć nowe, obdarzając bohaterki takimi cechami jak niezależność, wewnętrzna siła, aktywność itp. Uznały, że skoro baśń może utrwalać tradycyjne wzorce płci, może też zostać wykorzystana do przeciwdziałania tego rodzaju kulturowym tendencjom, reprezentującym patriarchalny obraz świata (Kostecka, 2014, s. 81).

Zgodnie z tą tezą feministyczny charakter adaptacji Adamsona i Amos może też przejawiać się $\mathrm{w}$ ich chęci do wyjścia poza diagnozę problemu. Napiętnowanie jednych postaw i nagradzanie drugich byłoby tu w zamierzeniu próbą rozwiązania konfliktów na tle pokoleniowym i płciowym.

Akcja musicalu dzieje się w królestwach Lagobel, położonym na pustyni i bogatym w złoto, oraz Sealand, położonym nad morzem i ubogim w kruszce. Pomiędzy złotym i niebieskim królestwem rozciąga się zielona puszcza, w której ukryte jest jezioro, tak ważne dla księżniczki. Od początku więc treść spektaklu obfituje $\mathrm{w}$ dychotomie, podkreślone zresztą silnie kontrastującymi 
barwami scenografii: woda i pustynia, pierwiastek męski i żeński. Althea, następczyni tronu Lagobel, i Digby, książę Sealandu, są na początku naturalnymi przeciwnikami, ale także swoimi lustrzanymi odbiciami. Podkreślają to równoległe koleje ich losów. W adaptacji pozbyto się postaci złej czarownicy - Althea traci ciężar i zdolność odczuwania smutku w reakcji na traumę spowodowaną śmiercią matki. Również Digby zostaje osierocony przez matkę jako dziecko. Po jej śmierci młody książę przestaje się uśmiechać, czym z czasem zdobywa sobie przydomek Posępnego Księcia.

Dwójka bohaterów odgrywa też kontrastowe role w swoich własnych rodzinach i królestwach. Digby uważany jest przez srogiego ojca i poddanych za posłusznego syna i dobrego następcę tronu. Z kolei Althea już w dzieciństwie zostaje przez ojca porzucona i zamknięta w wieży, podczas gdy on skupia się na wychowywaniu jej starszego brata Alexandra, przyszłego władcy. Althea nie pasuje do roli przewidzianej jej przez społeczeństwo, dlatego zostaje odrzucona. Jej izolacja pogłębia się, kiedy jej jedynymi towarzyszami stają się wspomniana już Piper oraz książki z baśniami należące do zmarłej królowej. Książki te stają się w musicalu jednym z wielu znaków infantylizacji głównej bohaterki. Kiedy na początku spektaklu Alexander ginie, pogrążona w świecie opowieści Althea nie chce nawet słyszeć o śmierci brata i o przejęciu obowiązków następczyni tronu. Skonfrontowana ze zrozpaczonymi poddanymi czy z żołnierzami własnej armii zmierzającymi na pewną śmierć na polu bitwy, księżniczka nie decyduje się okazać im wsparcia. Nalegania i apele ojca zbywa śmiechem, a w najlepszym przypadku - złością. Tę sytuację początkową kreśli wyraźnie piosenka My Own Land, w której Althea opisuje siebie jako „dziewczynę bez krzty powagi” (Adamson, Amos, 2013, s. 7), deklaruje niechęć do własnego królestwa, a także oświadcza pogodnie, że życie poza pałacem nie jest dla niej i wolałaby pozostać w wieży do końca swoich dni. Dojrzewanie przeraża księżniczkę. Kojarzy się jej jednoznacznie negatywnie z brzemieniem odpowiedzialności i szeregiem ról, w które chcieliby ją wtłoczyć zrozpaczony i oziębły ojciec oraz poddani.

Zgodnie z zamierzeniami twórców spektakl jest zapisem kolejnych konfrontacji księżniczki Althei ze światem zewnętrznym oraz stereotypami, które rodzina i społeczeństwo próbują jej narzucić jako kobiecie, córce, kochance i następczyni tronu. Niejednokrotnie walka ta nawiązuje do problemów współczesności w sposób bezpośredni. Staje się tak np. w scenie, w której jeden z kandydatów do ręki Althei jako lekarstwo na jej przypadłość rekomenduje przymusowe karmienie tak, aby księżniczka przytyła. Łatwo dostrzec tu nawiązanie do problemu coraz częściej występujących u młodych kobiet zaburzeń odżywiania, o których wspominają Warner (2013) i Byron (2013). Kolejnym przykładem 
może być piosenka Better Than Good, w której Althea opisuje pierwsze spotkanie z księciem Digbym, kiedy to doszło do pocałunku (Adamson, Amos, 2013, s. 41-43). Zachwyty podekscytowanej Althei, młodej zakochanej dziewczyny, przemieszane są z kwestiami chóru służących i poddanych, którzy wyzywają ją od wiedźm i zarzucają jej złamanie wszelkich zasad przyzwoitości z następcą tronu wrogiego królestwa. Surowa ocena fantazji i zachowań o zabarwieniu seksualnym dziewczyny może współcześnie budzić skojarzenie z takimi zjawiskami jak slut-shaming ${ }^{5}$, tj. budowanie i rozpowszechnianie negatywnej opinii na czyjś temat ze względu na zachowanie seksualne, czy obwinianie ofiar gwałtu o sprowokowanie sprawcy ubiorem lub postępowaniem postrzeganymi jako nieprzyzwoite.

Dorosłość w musicalu jest opresyjna, najeżona wymaganiami, które mogą budzić u osoby młodej niepokój, a nawet grozę. Choć pogodne spojrzenie na świat księżniczki w obu wersjach opowieści przedstawione jest jako eskapizm, warto odnotować istotną różnicę, którą jest ocena przypadłości księżniczki. MacDonald przedstawia stan nieważkości głównej bohaterki jako klątwę, stan nienaturalny, wymagający naprawy. Trudno oprzeć się wrażeniu, że wieczna dziecięca beztroska to skaza na charakterze księżniczki. Tymczasem zachowanie Althei nie spotyka się z takim samym napiętnowaniem w musicalu. Czasami musi wydawać się ono problematyczne, np. kiedy w odpowiedzi na wieści o nadciągających wojskach przeciwnika Althea odpowiada, że „aby coś się nie wydarzyło, wystarczy udawać, że nic się nie dzieje" (Adamson, Amos, 2013, s. 14). Księżniczka przedstawiana jest jednak głównie jako niewinna ofiara okropnych okoliczności, która nie radzi sobie $\mathrm{z}$ traumą. Dryfowanie w powietrzu i dobry humor budzą raczej empatię odbiorcy, który przestaje widzieć w nich coś jednoznacznie negatywnego czy niebezpiecznego. Takie przedstawienie jest zgodne z wizją Amos - to pod wpływem presji nieczułego i wymagającego otoczenia osobowość młodej dziewczyny ulega wypaczeniu, a ona sama cierpi najbardziej, kiedy brutalnie zmusza się ją do dorastania. Tym samym tekst adaptacji zostaje wzbogacony o nowe znaczenia, dopasowane do problemów dzisiejszej młodzieży opisywanych przez psychologów i socjologów. Jednocześnie jednak ulega rozmyciu przekaz tekstu oryginalnego o potrzebie dojrzewania. U MacDonalda dorosłość jest stanem pożądanym i pozytywnym, do którego należy dążyć.

Więcej na temat problemu slut-shamingu wśród młodych dziewcząt, a także o odpowiedzi środowisk feministycznych w postaci SlutWalks, piszą m.in. Jessica Ringrose i Emma Renold (2012). 
Tymczasem w musicalu Adamsona i Amos dorosłość przez większą część spektaklu sprawia przede wszystkim wrażenie więzienia.

Co więcej, dorosłość ta jest nierozerwalnie związana z płciowością. $\mathrm{W}$ adaptacji to ona wyznacza ramy tego, co akceptowalne, a przez to staje się też bezpośrednio kolejnym źródłem udręczenia głównych postaci. Digby cierpi, próbując wpasować się w stereotyp silnego, męskiego wojownika, który nie może sobie pozwolić na okazywanie uczuć. Z kolei Althea musi mierzyć się z opresyjną kobiecością, która pozostaje poza jej zasięgiem, a do której usiłują ją zmusić ojciec i poddani. W musicalu dochodzi do odwzorowania realnego problemu opisywanego przez Byron (2013). Odwołując się do użytych przez nią pojęć, można powiedzieć, że Althea zmaga się z eksternalizacją poczucia umiejscowienia kontroli - ciążące na niej oczekiwania sprawiają, że traci moc sprawczą we własnym życiu, podobnie jak młode kobiety skupione na dorównaniu medialnym standardom wyglądu za wszelką cenę.

Istotnym wątkiem w sztuce jest również temat macierzyństwa. Ojciec Althei, zrozpaczony postawą córki, postanawia wydać ją za mąż i zyskać potomka, który przedłuży ród i obroni królestwo. Choć niechętna pomysłom zamążpójścia i rodzenia dzieci, w drugiej części spektaklu Althea zachodzi w ciążę z Digbym. Dość nieoczekiwanie musical prezentuje macierzyństwo jako istotny element doświadczenia kobiecej dorosłości. Umiejscowienie tego wątku w końcowej fazie przedstawienia w połączeniu z nagromadzeniem wątków genderowych może sugerować, że jest to nieodzowny element przemiany młodej księżniczki w kobietę.

Uważny odbiorca spektaklu może odnieść wrażenie, że chcąc stworzyć nowoczesną, feministyczną wersję XIX-wiecznej baśni, Adamson i Amos osiągają w niektórych scenach skutek odwrotny do zamierzonego. Jak słusznie zauważa John Pennington (2015) w tekście poświęconym analizie porównawczej adaptacji Lekkiej księżniczki i tekstu oryginalnego, twórcy musicalu starają się niejako naprawić baśń MacDonalda, jednocześnie nie rozumiejąc konwencji gatunku (s. 89). Choć w libretcie pojawia się wiele odniesień do klasycznych opowieści, takich jak Dziewczynka z zapałkami (piosenka My Fairy-Story) czy baśnie braci Grimm, nawiązania te są powierzchowne (Adamson, Amos, 2013, s. 13-16). W przeciwieństwie do MacDonalda, który świadomie przetwarza wiele baśniowych wątków, w musicalu często są one odrzucane bez zastanowienia się nad ich znaczeniem dla struktury charakterystycznej dla gatunku. Jednym z przykładów takiego działania jest odrzucenie przez Adamsona i Amos postaci złej wiedźmy jako krzywdzącego kobiecego stereotypu. Choć takie rozwiązanie wynika $\mathrm{z}$ feministycznych przesłanek, może ono sugerować, że kobiety są zawsze dobre, a mężczyźni - zawsze źli, co prowadzi raczej do 
umocnienia szkodliwych schematów płciowych. Musical pełen jest idealizowanych, tragicznie zmarłych matek i okrutnych ojców. Wystarczy porównać to $\mathrm{z}$ baśnią MacDonalda, gdzie rodzice księżniczki odgrywają rolę głównych, w pełni ukształtowanych wzorców płciowych. Choć różnią się charakterem, żadne $\mathrm{z}$ nich nie zostaje przedstawione jako jednoznacznie dobre lub złe. Łączy ich uczucie, wzajemne zrozumienie i troska, a ich związek jest zaskakująco partnerski. Choć pierwszy rozdział baśni traktuje o problemach pary z poczęciem dziecka, złość króla na żonę zostaje przez nią samą szybko wykpiona i przedstawiona jako marudzenie zrzędliwego, choć kochanego i kochającego małżonka.

Skupienie na rolach płciowych i przedstawianie ich jako przeciwnych sobie zdaje się ograniczać wymowę musicalu. Pod koniec spektaklu Althea oddaje władzę w królestwie Piper, a sama zostaje badaczką flory i fauny wodnej, ale widz zostaje o tym poinformowany na sam koniec przedstawienia. Zakończenie to nie stanowi zatem integralnej części historii czy zwieńczenia narracji, a siła jego oddziaływania jest powierzchowna, co odnotowuje m.in. Catherine Love (2013) w swojej recenzji spektaklu. Podobnie jest z nagłymi i krótkotrwałymi wybuchami waleczności dziewczyny czy jej słownymi potyczkami z Digbym. Gdy ten po raz pierwszy widzi Altheę, jest natychmiast oczarowany i rozbawiony widokiem księżniczki unoszącej się nad jeziorem. Dziewczyna rozpoznaje w nim następcę tronu i dowódcę wojsk wrogiego królestwa, który na dodatek kilka chwil wcześniej próbował ją zastrzelić. Jest gotowa bronić się, grozi mu śmiercią. Dialog przechodzi w piosenkę Levity: Digby steruje lotem Althei za pomocą wstążek, którymi jest obwiązana (Adamson, Amos, 2013, s. 30-37). Rozdrażnienie księżniczki budzi wesołość Digby’ego. To wystarcza, aby Althea bez namysłu zapomniała o urazach i porzuciła dla przystojnego księcia wyznawane ideały. Piosenka kończy się pocałunkiem pary. Choć w warstwie słownej dziewczyna często podkreśla swoją niezależność, jej romans przypomina raczej ten tradycyjny i schematyczny, pojawiający się w literaturze i kulturze od lat. Książę i księżniczka zakochują się w sobie niemal od pierwszego wejrzenia. Althea najpierw odrzuca postawy i atrybuty związane z tradycyjną kobiecością, takie jak małżeństwo, uległość, rola żony i matki, przedmiotowość, aby następnie się im poddać. Jej postawa zmienia się w trakcie jednej sceny, dlatego też trudno mówić tu o procesie dojrzewania lub przemiany, który mógłby sugerować, że była to decyzja świadoma i odpowiednio umotywowana. Tym samym autonomia Althei i jej zerwanie $\mathrm{z}$ tradycyjnymi rolami płciowymi sprawiają wrażenie powierzchownych. W tekście poświęconym analizie atrybutów postaci kobiecych we współczesnej fantastyce dziecięcej i młodzieżowej Kostecka (2019) przywołuje pojęcie false feminizmu Amber 
E. Kinser (2004), który można rozumieć jako pozorne działanie o znamionach emancypacyjnych, nieniosące jednak ze sobą żadnej aktywności ani transformacji feministycznej. Kostecka (2019) pisze:

\begin{abstract}
„Aktywność" wyrażona jedynie pustym gestem polegającym na sięgnięciu po przedmiot czy strój zarezerwowany dotąd dla bohaterów płci męskiej oraz naśladowaniu "męskiego" stylu działania nie jest jeszcze aktywnością z ducha feministyczną. By za taką mogła być uznana, musi zasadzać się na czymś więcej niż tylko pustym geście; musi wynikać z relacji między danym artefaktem a jego właścicielką (s. 110).
\end{abstract}

Podobnie wygląda w tym kontekście zachowanie Althei. Na początku księżniczka chce odebrać Digby’emu miecz, ale kilka wersów później porzuca ten pomysł i godzi się zostać obiektem żartów księcia. Jej bunt pozostaje jedynie pustym gestem. Choć Althę i Digby'ego pod koniec przedstawienia łączy relacja i oboje przechodzą przemianę, nie mamy powodów, by przypuszczać, że udało im się oswobodzić z ról płciowych definiowanych zawsze przez czynniki zewnętrzne.

Tymczasem opowieść MacDonalda, ujęta w baśniowe ramy symboliki i uproszczenia, nabiera znacznie bardziej uniwersalnego charakteru. W tej wersji książę i księżniczka nie mają imion. Jednak, choć zawsze pozostają tylko swoimi rolami, role te potrafią zaskakiwać. Zgodny i równościowy związek króla i królowej znajduje swoje odzwierciedlenie w końcowej relacji księcia i księżniczki, w której partnerzy nie obawiają się odsłaniać przed sobą swoich słabości. Książę i księżniczka ratują się nawzajem: ona sama nie byłaby w stanie uratować jeziora, a on - wydostać się z wody. Choć nie są przedstawieni jako przeciwieństwa, uzupełniają się pod każdym względem. Ta narracyjna symetria może przypominać inne dzieło MacDonalda, nieprzetłumaczoną dotychczas na język polski baśń The Day Boy and the Night Girl (The Romance of Photogen and Nycteris) z 1882 roku. Opowiada ona o dwójce dzieci wychowanych przez czarownicę tak, aby chłopiec nie wiedział, czym jest noc, a dziewczynka - nie znała dnia. MacDonald kładzie w swej opowieści nacisk na komplementarny wymiar obu stron związku. Pod koniec baśni Photogen, uosobienie dnia, wyjaśnia, dlaczego chce poślubić Nycteris, uosobienie nocy:

[...] nigdy dwoje ludzi tak bardzo nie mogło się bez siebie obejść, jak ja i Nycteris. Ona musi mnie nauczyć, jak zachować odwagę w ciemnościach, a ja muszę się nią opiekować, póki nie będzie mogła znieść gorącego słońca i póki nie będzie ono jej pomagało widzieć, zamiast ją oślepiać (MacDonald, 1880/2009, s. 213). 
Tym samym MacDonald konsekwentnie przemyca do konwencji baśni koncepcje równościowe. Adamson i Amos zdają się nie dostrzegać, że wiele z idei, które chcieliby wprowadzić do świata Lekkiej księżniczki, jest już zawarte w jej oryginalnej wersji. W wywiadzie przeprowadzonym przez Paula Fostera (2014) Adamson zauważa, że tekst MacDonalda jest $\mathrm{w}$ istocie parodią baśni i deklaruje chęć oderwania się od tej konwencji (s. 17). Nie towarzyszy temu jednak pogłębiona analiza przekształceń, którym pisarz poddał wątki i strukturę opowieści typowych dla tego gatunku. Jak zauważa Pennington (2015), MacDonald dekonstruuje baśń i wprowadza do niej rozwiązania wyprzedzające epokę pod względem narracyjnym i społecznym (s. 87-89).

Podczas pracy nad adaptacją baśni szkockiego pisarza Adamsonowi i Amos przyświecała chęć ukazania wyzwań, które czekają na dojrzewającą dziewczynę. Przedstawiona przez nich droga do dorosłości jest niebezpieczna, pełna zagrożeń dla kobiecego (i męskiego) poczucia wartości, niezależności i jestestwa. Wydaje się jednak, że adaptując baśń literacką MacDonalda, autorzy libretta sami popadają w pułapki podobne do tych, które opisuje Jolanta Ługowska w analizie przejścia od bajki ludowej do baśni literackiej w XX-wiecznej literaturze polskiej. Badaczka odnosi się negatywnie do demontażu tradycyjnej konwencji baśniowej w imię szeroko pojmowanych wartości pedagogicznych:

Osobny i chyba nie najciekawszy rozdział w historii przygód pisarzy polskich z folklorem stanowi opracowywanie ludowych wątków z wyraźną intencją „aktualizacji” i „reinterpretacji” ich podstawowych sensów. [...] Analiza literacka parafraz wątków ludowych przeznaczonych dla najmłodszych czytelników wielokrotnie prowadziła do mniej lub bardziej zasadniczych zastrzeżeń dotyczących artystycznych efektów tych poczynań. Surowy przekaz ludowy nie może być bowiem potraktowany jedynie jako schemat otwarty na dowolne wypełnienia i uzupełnienia. Bajka ludowa okazuje się bowiem świadkiem samoistnym, wymagającym od pisarza znacznej kultury i erudycji folklorystycznych [...] (Ługowska, 1988, s. 87, 89-90).

MacDonald z pewnością posiadał wiedzę i umiejętności, o których pisze Ługowska. Stąd jego sprawne operowanie wątkami baśniowymi przy próbie przekazania ponadczasowych prawd dotyczących dojrzewania w wymiarze emocjonalnym i społecznym. Wizja Adamsona i Amos musi wydawać się mniej spójna i bardziej powierzchowna, ponieważ jej autorzy nie odwołują się jedynie do adaptowanej baśni literackiej, już przetworzonej, ale też do schematów baśni ludowej, których działania nie rozumieją w pełni. Tym samym ich nowoczesne poglądy na losy dorastających i dorosłych nie integrują się w pełni z resztą tekstu, tak jak dzieje się to w utworze powstałym półtora wieku wcześniej. 
Warto przywołać na koniec słowa samego MacDonalda (1864/2017a), tak opisującego moment, w którym książę odłącza się od swoich sług i po raz pierwszy znajduje jezioro księżniczki:

Lasy są bardzo pomocne w uwalnianiu książąt od ich dworzan [...]. Książęta są wówczas swobodni i mogą podążać za swoim przeznaczeniem. To sprawia, że mają przewagę nad księżniczkami, które są zmuszone do zamążpójścia, zanim się trochę zabawią. Chciałbym, żeby nasze księżniczki czasami gubiły się w lesie (s. 35).

To szczere życzenie szkockiego pisarza jest wyrazem tęsknoty za lepszą przyszłością dla kobiet - taką, która pozwoliłaby im na większą swobodę w odkrywaniu, kim są i co je czeka. Pod tym względem z całą pewnością MacDonald, Adamson i Amos pozostają całkowicie zgodni.

\section{Bibliografia}

Adamson, S. (libretto), Amos, T. (muzyka i libretto), Elliott, M. (reż.). (2013, 9 listopada). The light princess. Przedstawienie na żywo w National Theatre, Londyn.

Adamson, S., Amos, T. (2013). The light princess. London: Faber \& Faber.

Amos, T. (1992). Little Earthquakes [CD]. Los Angeles, CA, London: Atlantic, East West.

Amos, T. (2005). The Beekeeper [CD]. Los Angeles, CA: Epic.

Amos, T. (2007). American Doll Posse [CD]. Los Angeles, CA: Epic.

b.a. (b.d.a). Morbid. W: Merriam-Webster.com. Pobrane z: https://www.merriam-webster.com/dictionary/morbid.

b.a. (b.d.b). Morbidezza. W: Merriam-Webster.com. Pobrane z: https://www.merriamwebster.com/dictionary/morbidezza.

Belcher, D. (2013). First you cry, then you marry a prince. The New York Times. Pobrane z: https://www.nytimes.com/2013/10/06/theater/tori-amos-hopes-her-firstmusical-is-bleak-enough.html.

Bettelheim, B. (2010). Cudowne i pożyteczne. O znaczeniach $i$ wartościach baśni (D. Danek, tłum.). Warszawa: W.A.B. (wyd. oryg. 1976).

Billone, A. (2004). Hovering between irony and innocence: George MacDonald's The Light Princess and the gravity of childhood. Mosaic, 37(1), 135-148.

Byron, T. (2013). The Trouble with Girls. Program spektaklu rozdawany w National Theatre, Londyn.

Carter, A. (2000). Czarna Wenus. Opowiadania (A. Ambros, tłum.). Warszawa: Czytelnik. 
Chesterton, G. K. (1924). Introduction. W: G. MacDonald, George MacDonald and his wife (s. 9-15). New York, NY: MacVeagh.

Foster, P. (2014). The light princess: Background pack. Pobrane z: https://www.nationaltheatre.org.uk/sites/default/files/lightprincess_backgroundpack_final.pdf.

Gaiman, N. (2002). Dym i lutra. Opowiadania i złudzenia (P. Braiter, tłum.). Warszawa: Mag. (wyd. oryg. 1998).

Gaiman, N. (2015). Drażliwe tematy. Krótkie formy i stany zapalne (P. Braiter, tłum.). Warszawa: Mag.

Gleick, E. (1999, 24 maja). Books: Boo! (Scared Yet?). Time. Pobrane z: http://content. time.com/time/magazine/article/0,9171,991046,00.html.

Johnson, K. J. (2014). Rooted deep: Discovering the literary identity of mythopoeic fantacist George MacDonald. Linguaculture, 2, 25-44. https://doi.org/10.1515/ lincu -2015-0027.

Kaplan, I. (2015, 29 października). Tori Amos updated a 19th-century fairytale into a dark musical for today's youth. Nylon. Pobrane z: https://nylon.com/articles/toriamos-the-light-princess-interview.

Kinser, A. E. (2004). Negotiating Spaces for/through Third-Wave Feminism. NWSA Journal, 16(3), 124-153.

Klimek, K. (2011). Baśnie księżniczki popkultury. Dwutygodnik, 72. Pobrane z: http:// www.dwutygodnik.com/artykul/2967-basnie-ksiezniczki-popkultury.html.

Knopfler, M. (1979). Lady Writer [Dire Straits]. Z: Communiqué [CD]. London: Mercury Records.

Kostecka, W. (2014). Baśń postmodernistyczna: przeobrażenia gatunku. Intertekstualne gry z tradycja literacka. Warszawa: Wydawnictwo SBP.

Kostecka, W. (2019). Nowe wcielenia kobiecości? Atrybuty bohaterek współczesnej fantastyki dziecięcej i młodzieżowej. Prolegomena. W: A. Mik, M. Niewieczerzał, E. Rąbkowska, G. Leszczyński (red.), O czym mówia rzeczy? Świat przedmiotów w literaturze dziecięcej i młodzieżowej (s. 107-131). Warszawa: Wydawnictwo Naukowe i Edukacyjne SBP.

Lasoń-Kochańska, G. (2004). Córki Penelopy. Kobiety wobec baśni i mitu. Stupskie Prace Filologiczne. Seria Filologia Polska, 3, 173-182.

Le Guin, U. K. (2001). Otwarte przestworza i inne opowiadania. Poznań: Rebis. (wyd. oryg. 1996).

Love, C. (2013, 11 października). The Light Princess. Fairytale conventions. Exeunt. Pobrane z: http://exeuntmagazine.com/reviews/the-light-princess/.

Ługowska, J. (1988). Bajka w literaturze dziecięcej. Warszawa: Młodzieżowa Agencja Wydawnicza.

MacDonald, G. (1958). Na skrzydłach Pótnocnej Wichury (I. Tuwim, tłum.). Warszawa: Pax (wyd. oryg. 1871). 
MacDonald, G. (1990). Księżniczka i koboldy (M. Auriga, tłum.). Warszawa: Alfa. (wyd. oryg. 1872).

MacDonald, G. (2005). Królewna i Goblin (M. Sobolewska, tłum.). Warszawa: Fronda. (wyd. oryg. 1872).

MacDonald, G. (2009). The day boy and the night girl (The romance of Photogen and Nycteris). W: The complete fairy tales (s. 190-213). Overland Park, KS: Digireads. (wyd. oryg. 1880).

MacDonald, G. (2011). The Princess and the Goblin. London: Penguin Books. (wyd. oryg. 1872).

MacDonald, G. (2012). Królewna i goblin (M. Sobolewska, tłum.). Warszawa: Muchomor. (wyd. oryg. 1872).

MacDonald, G. (2017a). Lekka księżniczka (E. Kiereś, tłum.). W: Lekka księżniczka i inne baśnie (s. 5-69). Poznań: W drodze. (wyd. oryg. 1864).

MacDonald, G. (2017b). Serce olbrzyma (E. Kiereś, tłum.). W: Lekka księżniczka i inne baśnie (s. 115-146). Poznań: W drodze. (wyd. oryg. 1864).

MacDonald, G. (2017c). Złoty klucz (E. Kiereś, tłum.). W: Lekka księżniczka i inne baśnie (s. 71-113). Poznań: W drodze. (wyd. oryg. 1867).

Pennington, J. (2015). The not-so-light princess: Tori Amos and Samuel Adamson's reimagining of George MacDonald's classic fairy tale. North Wind, 34(1), 80-101.

Ringrose, J., Renold, E. (2012). Slut-shaming, girl power and 'sexualisation': Thinking through the politics of the international SlutWalks with teen girls. Gender and Education, 24(3), 333-343.

Rotter, J. B. (1966). Generalized expectancies for internal versus external control of reinforcement. Psychological monographs, 80(1), 1-28.

Warner, M. (2013). Writing to the future. Program spektaklu rozdawany w National Theatre, Londyn.

Warner, M. (2016). Alone of all her sex: The myth and the cult of the Virgin Mary. Oxford: Oxford University Press. (wyd. oryg. 1976).

Winterson, J. (1997). Płeć wiśni (Z. Batko, tłum.). Poznań: Rebis. (wyd. oryg. 1989).

Wróblewska, V. (2003). Przemiany gatunkowe polskiej baśni literackiej XIX i XX wie$k u$. Toruń: Adam Marszałek.

Zimmer Bradley, M. (2018). Mgły Avalonu (D. Chojnacka, tłum.). Poznań: Zysk i S-ka. (wyd. oryg. 1982).

Zipes, J. (2012). Fairy tales and the art of subversion: The classical genre for children and the process of civilization. New York, NY \& London: Routledge. (wyd. oryg. 1983). 